\title{
KOMUNIKASI KRISIS PT. JOUSKA FINANSIAL INDONESIA DALAM PEMULIHAN CITRA PERUSAHAAN
}

\author{
Isyraqi Khairy Siregar $^{1 *}$ dan Kurniati Putri Haeirina ${ }^{2}$ \\ ${ }^{1,2}$ Institut Komunikasi dan Bisnis LSPR, Jakarta - Indonesia \\ *isyraqikhairy@gmail.com
}

\begin{abstract}
Jouska is an independent financial advisory company that provides offline and online consulting services that recently went viral in social media and had a strong brand image as a financial consultant related to today's needs. In July 2020, social media was outraged by the complaint, which claimed to have been harmed by them, because Jouska allegedly directed their clients to determine an Investor Fund Account Management Contract (RDI) with PT Mahesa Strategies Indonesia, whose shares are affiliated with Jouska. However, during the development, the client experienced a significant loss in the shares. This situation turned out to be similar complaints from other clients until Jouska underwent a crisis that led to the government's blocking, and the case ended in the realm of law. This study aims to analyze the communication that presents Image Restoration Theory through a lens. The method used in this research is descriptive qualitative, and it was found that Jouska did not yet have a clear SOP for communication with clients and had not implemented crisis management appropriately. There are several recommendations that Jouska can achieve to restore public trust, including collaborative action with various parties, building a communication strategy, and optimal media relations.
\end{abstract}

Keywords: crisis communication; image restoration theory; jouska

\begin{abstract}
Abstrak
Jouska merupakan konsultan keuangan independen yang menyediakan konsultasi offline dan online yang sempat viral beberapa waktu belakangan karena konten-kontennya yang menarik dan fenomenal di sosial media. Jouska dianggap sebagai salah satu konsultan keuangan yang memberikan banyak ilmu mengenai keuangan yang relate dengan kebutuhan masa kini. Pada bulan Juli 2020, sosial media dikagetkan dengan complaint seseorang client yang mengaku dirugikan oleh Jouska, karena jouska mengarahkan clientnya untuk menandatangani Investor Fund Account Management Contract (RDI) with PT Mahesa Strategies Indonesia (Mahesa) yang sahamnya berafiliasi dengan Jouska, namun dalam perkembangannya saham client tersebut mengalami kerugian. Hal tersebut ternyata memunculkan complain serupa dari klien lainnya hingga Jouska mengalami krisis yang berujung kepada pemblokiran Jouska oleh pemerintah, dan kasus yang berakhir pada ranah hukum. Penelitian ini bertujuan untuk menganalisis krisis komunikasi yang dialami Jouska melalui kacamata teori Pemulihan Citra. Metode yang digunakan dalam penelitian ini adalah deskriptif kualitatif, dan hasil penelitian bahwa Jouska belum memiliki SOP komunikasi dengan client yang jelas dan belum menjalankan manajemen krisis dengan tepat. Terdapat beberapa rekomendasi yang dapat ditempuh Jouska untuk mengembalikan public trust,diantaranya: collaborative action dengan berbagai pihak, membangun strategi komunikasi, serta membangun media relations yang optimal.
\end{abstract}

Kata Kunci: komunikasi krisis; teori pemulihan citra; jouska

\section{PENDAHULUAN}

Internet telah mengubah cara manusia berkomunikasi dan berinteraksi satu sama lainnya, dan praktik public relations merupakan salah satu sektor yang turut beradaptasi akan hal tersebut. Beberapa fokus; seperti mengintegrasikan sosial media sebagai strategi komunikasi dalam meningkatkan kolaborasi digital yang diharapkan mampu membentuk persepsi publik yang positif bagi 
suatu perusahaan dalam memanfaatkan sosial media ketika menghadapi krisis. Organisasi memiliki potensi untuk memanfaatkan social media dalam berinteraksi dengan stakeholder yang massive dan beragam, namun di sisi lain kemunculan media sosial juga menginisiasi terjadinya resiko krisis (Cheng, 2018).

Sebagaimana disebutkan pada beberapa pengertian, tentunya praktisi public relations harus menyesuaikan mindset serta mengakomodasi penggunaan sosial media yang tepat dengan strategi yang dibentuk dalam menghadapi krisis komunikasi (Prastya, 2011). Namun, krisis pada era social media tidak memiliki batasan waktu, informasi dapat menyebar hanya dalam hitungan menit. Hal lainnya adalah dari sisi dampak, dampak reputasi sebuah organisasi yang terkena krisis jauh lebih riskan pada era digital ini, karena masyarakat dapat berperan secara lebih cepat untuk memberikan tanggapan terhadap suatu kasus. Dalam konteks perusahaan dengan adanya media baru menyebabkan pengendalian komunikasi krisis mengalami pergeseran, hal tersebut dilandasi oleh kecepatan dan ketidakpastian informasi, peningkatan rumor.

Terdapat beberapa hal yang membuat sosial media menjadi semakin penting untuk diperhatikan 1) Keinginan untuk dididik: pengguna sosial media semakin cerdas dalam memilih informasi, maka dari itu pesan atau informasi yang dirancang oleh suatu institusi akan lebih baik jika berdasarkan edukasi; 2) Pencarian sebuah percakapan: istilah citizen journalism semakin terkenal di masa kini, internet menjadi platform yang memungkinkan setiap orang untuk menjadi penulis dan membagikan pandangannya. Hal tersebut berpotensi membangun komunikasi antara perusahaan dengan audiensnya, sehingga menjadikan adanya sebuah percakapan; 3) Kebutuhan akan kinerja langsung: transformasi dunia digital menjadikan segala sesuatunya lebih real-time. Praktisi public relations dapat menggunakan kesempatan ini dalam mengembangkan strategi dalam merespons isu yang lebih cepat; 4) Kebutuhan akan adaptasi: penting bagi institusi untuk memetakan pesan yang spesifik berdasarkan target audiens. Sosial media merupakan tempat yang mampu mendorong hal tersebut menjadi nyata, karena institusi dapat menyampaikan informasi ke analis, konsumen atau opinion leaders hingga segmen publik lainnya (Seitel, 2014).

Sementara itu, (Salma, 2018) menyebut penggunaan internet sebelum, selama, dan setelah krisis dalam beberapa tahun terakhir telah berkembang menjadi cara paling populer bagi perusahaan untuk berkomunikasi dengan pemangku kepentingan dan publik utama, dan juga untuk mengakomodasi keterlibatan profesional public relations untuk menyusun rencana komunikasi krisis selama era digital ini. Saat ini, penanganan krisis dianggap tidak efektif jika hanya bertumpu pada cara-cara tradisional, karena saat ini setiap elemen komunikasi membutuhkan penggunaan internet. Internet telah secara dramatis mengubah cara menanggapi krisis. Akibatnya, penelitian tentang penggunaan internet dalam krisis komunikasi mendapat banyak perhatian ilmiah. Namun, banyak penelitian yang masih hanya berfokus pada penggunaan internet pada satu tahap. Penelitian ini menyajikan studi eksplanatori untuk memahami penggunaan Internet di semua tahapan krisis. Lebih lanjut, strategi komunikasi krisis di era digital tidak terbatas pada penggunaan internet sebagai media komunikasi, tetapi juga memperhatikan prinsip dan cara berkomunikasi.

Perkembangan teknologi digital memberikan output yang cukup signifikan terhadap komunikasi krisis. Terdapat dua hal yang perlu dicermati dalam situasi ini, yaitu: kanal komunikasi penyebaran informasi, pada era sebelumnya dimana social media belum eksis penyebaran komunikasi krisis hanya terpaku pada media konvensional seperti televisi, radio, atau surat kabar/koran yang mana informasi masih memiliki jeda waktu sebelum publik terpapar dan bereaksi terhadap suatu krisis (Akhyar \& Pratiwi, 2019).

Menurut (Brataas, n.d.) social media secara dramatis telah mengubah krisis komunikasi dan bagaimana krisis terjadi, bagaimana menggunakan sosial media yang 
baik merupakan hal yang vital untuk diperhatikan (Brataas, n.d.) juga menyebutkan benefit yang diberikan sosial media dalam menghadapi krisis, seperti: 1) Ketika krisis timbul, publik biasanya menunggu statement resmi yang dikeluarkan dari akun social media suatu institusi atau korporasi. Sebagai contoh adalah komunikasi krisis yang dialami oleh PT Sari Coffee Indonesia (Starbucks), yang mana pada beberapa waktu lalu sempat mengalami komunikasi krisis berupa pelecehan konsumen yang dilakukan seorang karyawan melalui CCTV. Social media Starbucks, khususnya Instagram dan Twitter langsung dipenuhi oleh pertanyaan publik terkait kasus yang terjadi, hingga pada akhirnya Starbucks merilis permintaan maaf secara resmi; 2) Social media dapat dipergunakan dengan bebas biaya, berbagai fitur sosial media yang dapat diakses kapanpun, menyediakan kemudahan berupa fitur yang bebas biaya. Hal ini tentunya sangat praktikal dalam membantu penyebaran informasi di kala krisis terjadi; 3) Social media yang bersifat real time memungkinkan berbagai pemberitaan muncul kapan saja tanpa adanya batasan, sehingga sangat wajar apabila krisis dapat diketahui publik lebih dahulu melalui social media dibandingkan media massa; 4) Berbeda dengan televisi yang menitikberatkan pada komunikasi satu arah, social media bersifat lebih interaktif. Social media menyediakan platform bagi organisasi untuk berkomunikasi dengan followersnya sehingga memungkinkan terjadinya dialog; 5) Pesan di sosial media dapat ditargetkan kepada kelompok yang spesifik; penting bagi praktisi public relations untuk menemukan media apa yang paling efektif untuk menyebarkan pesan tertentu, khususnya dalam mengatasi krisis komunikasi, tentunya penguasaan komunikasi digital sangat dibutuhkan; 6) Apabila penggunaan social media dilakukan dengan tepat, praktisi public relations memiliki potensi yang besar untuk mendapatkan analytics yang dapat memfasilitasi media monitoring dan perancangan strategi komunikasi; 7) Melalui social media, publik dapat menjadi "mata dan telinga" tambahan, dan mampu memberikan informasi tambahan terhadap suatu situasi. Hal ini in line dengan istilah citizen journalism, yang memungkinkan masyarakat luas memberikan informasi tambahan melalui data atau dokumentasi pribadi yang mereka miliki. Praktisi public relations dapat memanfaatkan hal tersebut sebagai alat tambahan yang mampu memperkuat strategi komunikasi dalam berbagai momen.

Pada praktiknya, sosial media dapat menjadi supporting tool bagi praktisi public relations dalam berkomunikasi di kala krisis, namun tidak menutup kemungkinan bahwa social media dapat memperburuk situasi krisis apabila tidak didampingi dengan manajemen krisis yang tepat. Setiap institusi, korporasi, maupun organisasi rentan menghadapi krisis. Kehadiran krisis dapat mengancam citra, keuangan, stabilitas, hingga keberlangsungan hidup suatu institusi. Krisis sebenarnya dapat berpotensi menjadi peluang bagi suatu institusi dalam bertransformasi ke arah yang positif, namun hal-hal negatif dapat saja muncul apabila pengelolaan krisis tidak dilakukan dengan optimal (Nova, 2014).

AirAsia mendapatkan rekognisi yang positif karena dianggap tanggap dan responsif terhadap krisis yang melanda maskapai ini pada penghujung tahun 2014 lalu. Berawal dari postingan Tony Fernandez, CEO AirAsia yang mengungkapkan rasa bela sungkawa terhadap keluarga korban jatuhnya pesawat AirAsia dengan nomor penerbangan QZ8501 dari Surabaya menuju Singapura dengan 162 orang penumpang dan crew di dalamnya hingga perubahan warna yang muram pada logo di sosial media dinilai berhasil dalam menyampaikan pesan duka di sosial media dan mendapatkan respons yang baik dari publik.

Namun, pada prakteknya social media juga bisa menjadi pisau bermata dua ketika krisis terjadi. Ketika krisis muncul bersamaan dengan berbagai pemberitaan serta informasi tambahan yang diberikan oleh publik semakin tidak terkendali, maka keberlangsungan hidup perusahaan dapat terancam atau bahkan hancur dalam waktu singkat. Sebagai contoh ialah 
penanganan kasus krisis komunikasi yang dihadapi oleh Jouska.

Spence et al., (2007) dalam Crisis Communication, Race, and Natural Disasters mendefinisikan krisis sebagai "Suatu peristiwa tertentu yang tak terduga dan tidak stabil atau serangkaian peristiwa yang menimbulkan ketidakpastian dan yang dianggap mengancam keberlangsungan perusahaan, yang nantinya juga menimbulkan perubahan, baik perubahan yang menguntungkan organisasi ataupun perubahan yang merugikan organisasi". Jika organisasi mengalami situasi krisis, maka prosedur-prosedur normal tidak dapat berjalan dengan baik. Organisasi akan mengalami situasi berbeda sehingga menyebabkan beberapa hal akan berubah secara spontan. Situasi seperti ini jika tidak segera ditangani dengan cepat dan tepat akan memberikan dampak yang negatif terhadap organisasi.

PT. Jouska Finansial Indonesia merupakan perusahaan penasihat keuangan independen yang didirikan oleh tiga orang dengan background finance pada tahun 2013, ketiga Co-Founder tersebut ialah Aakar Abyasa, Indah Hapsari, serta Farah Dini. Jouska mengakomodir berbagai kebutuhan klien yang berhubungan dengan masalah keuangan, asuransi, manajemen cash flow, perpajakan dan hukum, dana pensiun, dana pendidikan hingga asuransi (Hafsah, 2018). Menurut CNN Indonesia (2020), Jouska memberikan input finansial yang merujuk kepada kondisi keuangan serta objektif dari setiap klien yang menyesuaikan kepada tren analisis ekonomi terkini.

Jouska menyediakan layanan konsultasi secara offline maupun online, juga dalam bentuk aplikasi yang dapat di unduh. Tidak hanya itu, Jouska pun turut meramaikan jagat media sosial, khususnya di Twitter dan Instagram. Minjou, (panggilan untuk Admin Jouska) sangat aktif berkomunikasi dengan netizen yang kebanyakan merupakan millennials, ditambah dengan presentasi visual design yang modern, serta topik seputar tips keuangan yang relatable dengan kebutuhan masa kini, membuat Jouska sukses meraih perhatian banyak orang. Sebelum kasus krisisnya mencuat, Jouska tidak pernah diberitakan memiliki masalah dengan operasional perusahaan. Berbagai aktivitas yang dilakukan Jouska di Sosial Media membuahkan citra yang baik bagi perusahaan.

Citra didefinisikan sebagai sebuah kesan yang timbul sebagai hasil dari pemahaman dan usaha yang terbentuk dari pengalaman dalam memandang suatu perusahaan atau organisasi. Citra bersifat abstrak dan tidak bisa diukur secara sistem, namun perwujudannya dapat dirasakan dari hasil jerih payah yang dilakukan seperti menerima penghargaan dan dukungan positif yang khususnya datang dari publik (Mahanani, Christianti, \& Uljanatunnisa, 2020). Hal ini dibuktikan dengan Jouska yang acapkali mendapatkan feedback positif dari masyarakat terkait kontennya yang dianggap memberikan insight baru terhadap keuangan, khususnya bagi orang awam. Kasus yang diangkat sebagai topik juga dianggap fenomenal, salah satunya mengenai tingginya harga pendidikan tingkat TK di Jakarta yang sempat ramai pada penghujung 2019 lalu.

Hingga pada Juli 2020, media sosial diramaikan oleh komplain seorang klien yang menyatakan bahwa dirinya telah dirugikan oleh financial advisor tersebut. Kasus tersebut bermula saat Jouska menginstruksikan kliennya untuk menandatangani kontrak pengelolaan akun dana investor (RDI) dengan PT Mahesa Strategies Indonesia (Mahesa) terkait pengelolaan dana investasi. Belakangan diketahui bahwa Mahesa adalah sebuah perusahaan dan sahamnya terkait dengan Jouska. Dalam proses pengembangannya, Mahesa menggunakan dana investasi klien untuk membeli berbagai saham dan reksa dana, salah satunya adalah pembelian saham PT Sentral Mitra Informatika Tbk (LUCK). Tren saham LUCK yang sudah untung selama delapan bulan tiba-tiba ambruk sehingga merugikan aset klien Jouska. Penyebaran virus klien ini sebenarnya memicu persetujuan klien lain yang mengaku sebagai korban Jouska, dan masalah tersebut akhirnya dilaporkan ke pihak 
berwenang. Kelompok Kerja Waspada Investasi (SWI) juga mengambil tindakan dan menghentikan seluruh operasional penasehat keuangan. Jouska diduga terlibat dalam kegiatan konsultasi investasi tanpa izin, manajer investasi, atau perusahaan sekuritas. SWI memblokir situs web, aplikasi, dan media sosial Jouska melalui Kementerian Komunikasi dan Informasi.

Dalam perkembangan kasusnya, Jouska tengah memproses perjanjian damai dengan kliennya. Kemarahan klien tidak terbendung, dan mereka semua menuntut Jouska untuk mengkompensasi semua dana kerugian. Menurut manajemen, terdapat keterlambatan pengembalian dana kepada klien disebabkan karena banyaknya pihak yang terlibat dalam proses tersebut. Aakar Abyasa, Co-founder dan CEO Jouska, mengatakan bahwa proses penyelesaian dana tidak dilakukan antara Jouska dengan kliennya, melainkan oleh PT Mahesa Strategis Indonesia, perusahaan yang menandatangani perjanjian dengan klien Jouska untuk investasi saham. Tidak sampai disitu, ternyata terdapat permasalahan lain yang ikut timbul. Setelah dilakukan penelusuran lebih mendalam, ternyata Jouska masih belum memiliki izin resmi di bawah Otoritas Jasa Keuangan (OJK). Tujuan penelitian ini adalah untuk menganalisis komunikasi krisis dari PT Jouska Finansial Indonesia ketika krisis melanda.

Untuk memperkuat penelitian ini maka peneliti menggunakan Teori Pemulihan Citra (Image Restoration Theory) dari Benoit (1997). Citra mengacu pada hal yang dirasakan organisasi oleh stakeholder dan publiknya. Kunci untuk mengerti teori pemulihan citra atau image restoration theory ini adalah mempertimbangkan untuk memberikan respon yang cepat dan tepat terhadap serangan atau keluhan yang terjadi pada masa krisis, Benoit mengatakan dia menyarankan untuk memperhatikan dua komponen yang perlu diperhatikan ketika terjadi krisis yang terkait dengan pencitraan. Pertama organisasi harus memberikan tanggung jawab dengan melakukan tindakan, kedua tindakan yang dibangun tersebut harus berkaitan mempertimbangkan efek yang akan muncul dan diharuskan efek yang dimuculkan tersebut memunculkan reaksi yang positif (Roberts, 2006).

Sementara itu kajian literatur yang digunakan dalam penelitian ini Mahriva (2020)dengan judul Corporate Communications PT. XL Axiata Tbk. Merespon Masa Krisis Pandemi Virus Covid19. Penelitian bertujuan untuk meneliti bagaimana respon corporate communication PT. XL Axiata Tbk. apabila Covid-19 berlangsung lama sehingga menjadi krisis. Penelitian ini menggunakan konsep krisis public relations dan tahapan krisis dari Steven Fink. Sementara Hasil penelitian menunjukkan bahwa corporate communication (komunikasi korporasi) sudah membentuk Emergency Response Team (ERT sebelum ada krisis, divisi ini sudah dilatih untuk merespon, mengantisipai dan menghadapi serta mengtasi segala krisis dengan tepat dan cepat krisis perusahaan telekomunikasi PT. XL Axiata Tbk.

Penelitian kedua adalah hasil penelitian dari (Mahanani, Christianti, \& Uljanatunnisa, 2020) dengan judul Strategi Komunikasi Organisasi Fungsi HSSE PT. Pertamina Patra Niaga Dalam Menjaga Citra Perusahaan. Tujuan penelitian adalah untuk mengetahui strategi komunikasi organisasi yang dilakukan oleh Fungsi HSSE (Health, Safety, Security and Environment) PT Pertamina Patra Niaga dalam mencegah segala resiko yang mungkin terjadi dan berpotensi mempengaruhi citra perusahaan. Teori yang digunakan Komunikasi Organisasi yaitu Sibernatika dengan menggunakan konsep Citra. Sementara Hasil penelitian ini memperlihatkan bahwa Fungsi HSSE PT Pertamina Patra Niaga merupakan sebuah fungsi yang penting dalam menjaga citra perusahaan. Fungsi ini terbentuk atas pentingnya aspek keselamatan pada perusahaan yang padat akan resiko (high risk).

Persamaan dari kedua penelitian tersebut dengan penelitian ini sama-sama mengangkat fenoemen krisis pada perusahaan dengan strategi yang dilakukan masing-masing 
perusahaan. Sementara perbedaannya pada teori dan konsep yang digunakan dan konteksnya juga berbeda sehingga hasil penelitian juga berbeda ada kebaruan dari penelitian-penelitian sejenis atau penelitian terdahulu.

Dari latar belakang dan kajian literatur tersebut maka penelitian ini bertujuan untuk menganalisis krisis komunikasi yang dialami Jouska. Penelitian dinalisis melalui kacamata Teori Pemulihan Citra dengan menggunakan metode studi kasus.

\section{METODOLOGI PENELITIAN}

Penelitian ini merupakan penelitian deskriptif kualitatif, (Intani, 2018) penelitian kualitatif berakar dari kebutuhan mengendalikan manusia sebagai alat penelitian, serta menggunakan metode kualitatif dan menganalisis data secara induktif untuk mengarahkan sasaran penelitian pada usaha menemukan teori dari dasar yang bersifat deskriptif. Menurut Creswell dalam pendekatan kualitatif dipergunakan untuk mengkaji, meneliti, hingga menganalisis permasalahan hingga titik permasalahan tersebut dapat ditemukan. Sementara metodologi bertujuan untuk memfokuskan diri pada cara kita meraih pengetahuan tentang dunia. (Denzin \& Lincoln, 2009). Pengumpulan data dilakukan dalam berbagai setting, berbagai sumber dan berbagai metode.

Penelitian ini menggunakan metode kualitatif dan strategi studi kasus. Tujuan dari analisis kualitatif adalah untuk menjelaskan studi kasus tersebut. Sedangkan studi kasus digunakan untuk memfokuskan pada kasus yang terjadi berdasarkan masalah yang akan digeneralisasikan, sehingga hasil analisis dapat diterapkan pada kasus serupa dengan objek yang berbeda. Melalui pelacakan partikularitas suatu kasus secara efektif. Manfaat dan kegunaan studi kasus bagi para praktisi dan pembuat kebijakan terletak pada aspek perluasan pengalamannya (its extension of experience). Dengan demikian secara garis besar, metode studi kasus adalah metode penelitian pribadi dan kajian tentang pengalaman personal yang unik (Denzin \& Lincoln, 2009).

Metode penelitian ini adalah studi kasus yang dianalisis adalah kasus krisis di Jouska yang dipimpin oleh Aakar Abyasa yang bergerak di industri financial advisory. Jouska adalah penasihat keuangan independen yang menawarkan konsultasi offline dan online karena kontennya yang menarik dan menarik di media sosial, yang akhir-akhir ini menjadi populer. Kehadiran Jouska dianggap sangat relevan dengan kebutuhan literasi finansial saat ini. Namun pada Juli 2020 media sosial dihebohkan dengan keluhan pelanggan yang mengaku dirugikan oleh Jouska karena menginstruksikan pelanggan untuk menandatangani kontrak pengelolaan akun dana investor dengan PT Mahesa Strategies Indonesia (Mahesa) (RDI), saham perusahaan. milik Jouska, namun dalam perkembangannya, nasabah mengalami kerugian. Fakta membuktikan bahwa hal ini menimbulkan keluhan serupa dari client lain, yang menyebabkan Jouska mengalami krisis komunikasi dengan berujung pemberhentian operasional financial advisor tersebut dan perkembangan kasus yang diproses ke ranah hukum.

\section{HASIL DAN PEMBAHASAN}

Dikutip dari Idris (2020), perkembangan kasus Jouska dimulai dari viralnya financial advisor tersebut dan meramaikan media sosial dengan konten finansial yang menarik, membuat banyak orang mengetahui keberadaan konsultan keuangan ini. Isu terkait Jouska mulai bermunculan, diduga Jouska dianggap mempengaruhi klien untuk menandatangani kontrak pengelolaan akun dana investor dengan PT Mahesa Strategis Indonesia (MSI). Dalam perkembangannya, dana investasi digunakan untuk membeli beberapa saham, termasuk PT Sentral Mitra Informatika (LUCK). Nilai portofolio saham LUCK yang baru saja melakukan Penawaran Umum Perdana di Bursa Efek Indonesia pada akhir tahun 2018 turun sehingga menyebabkan kerugian yang signifikan salah satu klien 
Jouska merasa dirugikan dengan rekomendasi yang diperoleh dan membagikan pengalamannya di Twitter. Tindakan ini memicu keluhan lain yang muncul dari klien yang juga mengalami hal yang sama hingga isu tersebut menjadi trending.

Berdasarkan IDN TIMES (2020), telah teridentifikasi 21 klien yang mengalami kerugian, ditambah laporan-laporan yang diikuti hingga total akhir 45 klien. CEO Jouska Aakar Abyasa mengumumkan permintaan maaf kepada klien, pemangku kepentingan dan masyarakat luas melalui Instagram pribadinya dan menyatakan bahwa Jouska akan siap untuk mengikuti peraturan hukum yang sesuai. Otoritas Jasa Keuangan (OJK) telah menghentikan operasi Jouska, serta Satgas Waspada Investasi (SWI) bekerja sama dengan Kementerian Komunikasi dan Informatika telah memblokir semua Media Sosial Resmi dan Platform Digital Jouska. Dikutip dari (Tari, 2020) tahapan kasus Jouska saat ini sedang dalam proses konstruksi, terutama pemeriksaan dan pendalaman ke Jouska oleh OJK dan regulator.

Setelah kasus ini muncul di publik, internal Josuka khususnya Aakar Abyasa selaku CEO melakukan beberapa pembelaan yang dapat dikaitkan dengan Image Restoration Theory. Image Repair adalah salah satu teori komunikasi krisis yang paling banyak digunakan. Adaptasi tipologi untuk lembaga pemerintah, organisasi (baik nirlaba maupun nirlaba), selebriti, dan politikus membuatnya menarik bagi para sarjana. Strategi yang dirinci dalam teori juga berharga dalam melatih juru bicara untuk secara sadar memilih pendekatan yang paling tepat untuk mengurangi krisis. Namun kekuatan ini juga menjadi perhatian. Beberapa sarjana khawatir bahwa perbaikan citra memberi juru bicara strategi untuk menghindari hukuman atas perilaku tidak etis. Meskipun teori itu sendiri tidak secara terangterangan menjelaskan penyalahgunaan strategi, dalam tulisannya Benoit secara konsisten bersikukuh bahwa asumsi utama teori perbaikan citra adalah bahwa setiap pelanggaran standar etika harus diungkapkan dan ditangani secara terbuka. Seperti Teori Apologia, tanggung jawab untuk bergerak melampaui deskripsi ke evaluasi efektivitas diserahkan kepada penulis. Akibatnya, para sarjana menerapkan tipologi tersebut tanpa melanjutkan ke evaluasi dan implikasi studi mereka (Sellnow \& Seeger, n.d.). Berikut merupakan tahapan Image Restoration Theory yang dianalisis melalui kasus krisis Jouska:

\section{Denial, Shifting the blame}

Aakar Abyasa menepis tudingan bahwa timnya telah melakukan pelanggaran otoritas dengan melakukan pengelolaan serta mentransaksikan saham klien. Aakar menekankan bahwa klien memiliki hak untuk menerima atau menolak masukan yang diberikan. Dikutip dari (IDNTIMES, 2020) Aakar menyatakan bahwa pihaknya terbuka untuk melakukan diskusi. Pada tahapan ini Jouska mentransfer kesalahan mereka kepada pihak lain dan memberikan impresi bahwa pihak lain memiliki power untuk menentukan pilihannya dalam bertransaksi, sehingga kesalahan tidak murni hadir dari pihaknya. Selain itu, Jouska juga berusaha mengakomodasi penyebab insiden dengan memberikan kesempatan berkomunikasi.

\section{Evading Responsibility}

Good intention: Aakar Abyasa menjelaskan mengapa Jouska merekomendasikan kliennya untuk berinvestasi pada saham LUCK. Pertama, informasi mengenai perusahaan tersebut dapat diakses secara terbuka melalui IDX, dan ketika kontrak telah ditandatangani perusahaan juga mendapatkan profit yang baik dari sahamnya (IDN TIMES, 2020). Hal ini dapat diidentifikasi sebagai bentuk good intention, dimana Jouska bermaksud untuk memberikan niat baik kepada kliennya tanpa bermaksud menjerumuskan dengan alasan bahwa perkembangan saham LUCK yang awalnya menguntungkan.

\section{Reducing Offensiveness of Event \\ Minimization: Jouska menyatakan bahwa mereka telah berkomunikasi dengan berbagai}


pihak yang terkait dalam kasus ini. Selain itu, Jouska juga berjanji untuk memenuhi investigasi oleh Satgas Waspada Investasi (SWI) dengan menjadi kooperatif dan terbuka dengan regulator. Pada tahapan ini, Jouska berusaha untuk mengurangi kepanikan publik dengan mempersuasi bahwa keadaan akan baik-baik saja, dan menunjukkan tanggung jawab mereka demi mengurangi persepsi negatif yang tercipta.

Compensation: Jouska mengklaim bahwa mereka sudah mencapai persetujuan dengan empat puluh lima klien pada konferensi pers yang dijalankan pada tanggal 1 September 2020. CEO Jouska menyatakan bahwa persetujuan rekonsiliasi memiliki perbedaan antara klien, sebagian mendapatkan refund sementara yang lainnya mendapatkan pengembalian saham dari LUCK (Aldin, 2020). Jouska berusaha untuk membenahi kesalahannya dengan bertanggung jawab dan berjanji untuk mengembalikan kerugian berbagai pihak. Tindakan ini dilakukan tentunya sebagai kompensasi untuk memperbaiki reputasi.

\section{Corrective action}

Dikutip dari (Sari, 2020) Aakar Abyasa menyatakan bahwa adanya komunikasi yang intens antara financial advisor Jouska dengan kliennya, termasuk memeriksa portofolio saham pihak ketiga hal ini menciptakan kesalahpahaman yang membuat klien menyamakan posisi jouska dengan pihak ketiga. Aakar menjelaskan bahwa di masa depan Jouska perlu menerapkan standar komunikasi yang lebih jelas, ia juga berjanji akan menemukan solusi terbaik untuk keadaan finansial kliennya.

Mortification: strategi ini merupakan langkah terakhir dalam tahapan Image Restoration Theory yang diterapkan dalam keadaan krisis, contohnya ialah mengakui kesalahan serta menyatakan permohonan maaf terhadap kesalahan yang terjadi, yang mana pada kasus ini Jouska merilis permohonan maaf secara resmi yang diunggah ke social media.

Untuk memperkuat substansi hasil analisis dan studi literatur terhadap kasus krisis komunikasi Jouska, peneliti juga melakukan wawancara dengan praktisi dan penulis buku Public Relations, yaitu Bapak Nico Wattimena, Ph.D. Wawancara dan diskusi antara peneliti dan narasumber dilakukan melalui sambungan telepon.

Peneliti mengkonfirmasi mengenai bagaimana perkembangan kasus Jouska jika dilihat dari kacamata krisis komunikasi: "Jouska memiliki kelebihan dimana mereka dapat membangun public trust, sehingga masyarakat dapat percaya untuk menggunakan jasa financial advisor ini, terutama Aakar Abyasa, yang merupakan CEO dari Jouska. Jika kita lihat dari perkembangan kasusnya, sang CEO merupakan orang yang paling sering muncul dan berbicara ke depan media, hal ini menunjukkan bahwa sebenarnya ia adalah seorang good PR, secara person ia jago" (N. Wattimena, personal communication, January 4, 2021).

Menurut narasumber, Jouska dapat memanfaatkan social media dengan sangat optimal, hal ini dibuktikan dengan kontenkonten Jouska di media sosial yang sangat beragam dan komunikatif, selain itu Jouska juga punya kelebihan dalam mengemas konten menjadi suatu hal yang trending dengan perkembangan zaman masa kini.

"Social media merupakan tools sangat bagus untuk PR dengan catatan apabila PR tahu celah untuk memanfaatkannya. Hal tersebut tercermin dari Jouska. Namun jika kita tidak cerdas dalam memanfaatkan social media akan menimbulkan bahaya, hal ini sangat bergantung kepada cara pemanfaatannya. Jouska sangat bagus dalam memanfaatkan sosmed, sampai memunculkan trust di masyarakat dan kliennya, hingga banyak orang yang berani melakukan aktivitas yang high risk atas saran Jouska" (N. Wattimena, personal communication, January 4, 2021).

Peneliti mencoba menggali informasi kepada narasumber terkait inti permasalahan 
dari krisis komunikasi Jouska. "Pertama ialah izin usaha, jika kita telisik dari pemberitaan, ternyata Jouska masih belum memiliki izin. Mereka terdaftar 6 Maret 2018 dengan nomor SK Pengesahan AHU-0014429.AH.01.01. tahun 2018 bukan sebagai perusahaan yang bergerak dibidang financial advisor. hal ini juga merupakan sebuah masalah legal, seharusnya klien bisa lebih smart dalam mencari informasi mengenai Jouska. Seharusnya klien bisa bersifat lebih hati-hati, apalagi setelah kasus ini mencuat, publik baru mengetahui bahwa jouska masih belum memiliki izin operasional" (N. Wattimena, personal communication, January 4, 2021).

Selain itu menurut narasumber, posisi Jouska hanyalah sebagai planner atau advisor, sehingga klien memiliki kendali untuk mengikuti saran mereka atau tidak. "Setiap bisnis atau saham pasti ada yang high risk atau low risk, dan apabila client berani mengambil langkah yang high risk, jouska berarti punya kemampuan komunikasi yang baik dalam mempersuasi kliennya. (N. Wattimena, personal communication, January 4, 2021).

Sebagai penutup, peneliti bertanya apakah ada kesempatan untuk Jouska bangkit dan kembali eksis di dunia konsultasi keuangan di Indonesia. Dalam situasi ini, kemungkinan untuk re-branding sepertinya kecil. Mungkin ada kesempatan, namun CEO nya jangan muncul lagi, karena ia sudah menjadi sorotan publik. Fungsi Public Relations di Jouska perlu diperbaiki, karena sepertinya tidak berjalan dengan baik. CEO memang bisa menjadi spoke person dan sangat baik apabila CEO menunjukkan responsibility ketika krisis terjadi, namun hal ini harus diimbangi dengan kemunculan pihak lain". (N. Wattimena, personal communication, January 4, 2021).

\section{SIMPULAN}

Jouska telah memiliki brand image yang kuat, dengan positioning sebagai financial advisor yang modern dan aktif di sosial media. Namun, krisis yang terjadi tidak ditangani dengan krisis manajemen yang siap sehingga berujung kepada kehancuran organisasi.
Beberapa hal yang perlu diperhatikan dalam kasus ini adalah penetapan standar komunikasi Jouska dengan klien yang menyebabkan Jouska keluar dari batasannya sebagai financial advisor. Selain itu, Jouska juga tidak responsif dalam meminimalisir perkembangan isu di media sosial, yang mana ketika kasus ini mulai terangkat Jouska tidak segera berkomunikasi secara pribadi dengan pihak yang melayangkan keluhannya.

Melihat perkembangan kasus Jouska yang kini berada dalam tahap litigasi, beberapa langkah rekomendasi berikut dapat diterapkan oleh Jouska. Pertama, penting bagi Jouska untuk melakukan collaborative action dengan berbagai pihak, mulai dari ahli komunikasi, financial consultant, hingga regulator untuk membangun strategi komunikasi yang holistic dengan menentukan sebuah key message dan tujuan komunikasi. Selain itu penting juga bagi Jouska untuk mengoptimalkan media relations, tujuannya sebagai sarana keterbukaan informasi selama kasus ini sedang ditangani. Hal ini diharapkan mengurangi perkembangan pemberitaan yang membingungkan serta semakin berpengaruh kepada citra negatif Jouska. Memperbaiki standar komunikasi yang transparan juga merupakan hal vital yang perlu dilakukan oleh Jouska, apabila terdapat kemungkinan untuk melakukan re-branding dan mengembalikan public trust di masa depan.

\section{DAFTAR PUSTAKA}

Akhyar, D. M., \& Pratiwi, A. S. (2019). Media Sosial dan Komunikasi Krisis: Pelajaran dari Industri Telekomunikasi di Indonesia. Jurnal Ultima Comm, 11(1), 35-52. https://ejournals.umn.ac.id/index.php/F IKOM/article/view/1112/777

Brataas, K. (n.d.). (2018). Crisis Communication: Case Studies And Lessons Learned From International Disasters. Routledge, Taylor \& Francis Group.

Cheng, Y. (2018). How Social Media Is Changing Crisis Communication Strategies: Evidence from the Updated 
Literature. Journal of Contingencies and Crisis Management, 26(1), 58-68. https://doi.org/10.1111/14685973.12130

CNN Indonesia, (2020, July 22). Jouska, Perusahaan Perencanaan Keuangan yang Sering Viral. CNN Indonesia. Diakses dari https://www.cnnindonesia.com

Denzin, N. K., \& Lincoln, Y. S. (2009). Handbook of Qualitative Research (2nd ed.). SAGE.

Hafsah, A. (2018). Jouska Indonesia: Konsultan Keuangan Independen. Diakses dari https://yooreka.id/workspace/jouskaindonesia-konsultan-keuanganindependen/

IDN Times, (2020, July 24). Dituding Rugikan Klien, Ini Penjelasan Lengkap Founder Jouska. IDN Times. Diakses dari https://www.idntimes.com

Idris, M., (2020, July 25). Kronologi Lengkap Kasus Dana Investasi Jouska hingga Diblokir OJK. Kompas.com. Diakses dari https://money.kompas.com/

Indasari, F., \& Anggriani, I. (2020). KRISIS KOMUNIKASI PADA MASA PANDEMI COVID-19 (Studi Kasus Pemberitaan Penyebaran Covid-19 melalui Udara). Profesional: Jurnal Komunikasi dan Administrasi Publik, 7(1), 1-11. https://doi.org/10.37676/professional.v 7i1.1086

Intani. R. 2018. Strategi Public Relations PT. Pelni (Persero) Mengimplementasi Program CSR Melalui Program Kemitraan dan Bina Lingkungan. Jurnal Pustaka Komunikasi, 1(1), 130146. https://journal.moestopo.ac.id/index.ph $\mathrm{p} /$ pustakom/article/view/549

Maharani, F. P., Christanti, M. F., dan Uljanatunnisa, U. (2020). Strategi Komunikasi Organisasi Fungsi HSSE PT Pertamina Patra Niaga dalam Menjaga Citra Perusahaan. Jurnal Pustaka Komunikasi, 3(1), 100-111. https://journal.moestopo.ac.id/index.ph $\mathrm{p} /$ pustakom/article/view/998.

Nova, F. (2014). PR War. Jakarta: PT. Grasindo.

Prastya, N. M. (2011). Komunikasi Krisis di Era New Media dan Social Media. Jurnal Komunikasi, 6(1), 1-20. https://doi.org/10.20885/komunikasi.vo 16.iss1.art1.

Salma, A. N. (2018). Strategi Komunikasi Krisis pada Era Digital: Penggunaan Internet Dari Sebelum Hingga Sesudah Krisis. Jurnal Penelitian Pers Dan Komunikasi Pembangunan, 22(1), 1936. https://doi.org/10.46426/jp2kp.v22i1.7 1

Sari. I. N. (2020, September 1). CEO Jouska akui lalai dalam komunikasi dengan klien. Kontan.co.id. Diakses dari https://investasi.kontan.co.id/

Seitel, F. P. (2014). Praktik Public Relations. 12th ed. Jakarta: Erlangga.

Sellnow, T. L., \& Seeger, M. W. (2013). Theorizing Crisis Communication (1st ed.). Cichester, UK: Wiley-Blackwell.

Tari, D. N. (2020, August 10). OJK Ungkap Perkembangan Kasus Jouska dan Suspensi Reksa Dana Kresna AM. Bisnis.com. Diakses dari https://market.bisnis.com/

Wattimena, N. (January 4, 2021). Personal Interview. 